\title{
A Participatory GIS Approach to Identify Critical Land Degradation Areas and Prioritize Soil Conservation for Mountainous Olive Groves (Case Study)
}

\author{
Ahmed AL-WADAEY', Feras ZIADAT2* \\ 1 Soil and Water Department, Faculty of Agriculture, Sana'a University, Sana'a oog67, the Republic of Yemen \\ 2 International Center for Agricultural Research in the Dry Areas (ICARDA), P.O. Box 950764 - Amman 11195, Jordan \\ *Corresponding author, e-mail: f.ziadat@cgiar.org; First author,e-mail: aalwadaey@gmail.com
}

Citation: Al-wadaey A, Ziadat F (2014) A participatory GIS approach to identify critical land degradation areas and prioritize soil conservation for mountainous olive groves (case study). Journal of Mountain Science 11(3). DOI: 10.1007/s11629-0132827-x

(C) Science Press and Institute of Mountain Hazards and Environment, CAS and Springer-Verlag Berlin Heidelberg 2014

\begin{abstract}
Climate change scenarios predict an increase in the frequency of heavy rainfall events in some areas. This will increase runoff and soil erosion, and reduce agricultural productivity, particularly on vulnerable mountainous agricultural lands that is already exhibiting high rates of soil erosion. Haphazard implementation of soil and water conservation (SWC) interventions on scattered fields is inefficient in reducing soil erosion. The objective of this study was to identify areas at high risk of erosion to aid the design and implementation of sustainable SWC using GIS analysis and farmers' participation approach. A $25 \mathrm{~m}$ digital elevation model (DEM) was used to derive layers of flow accumulation, slope steepness and land curvature, which were used to derive an erosion-risk (priority) map for the whole watershed. Boundaries of farmers' fields were mapped and verified by the community and each field was classified into high, moderate or low erosion risk. Fields with low flow accumulation (top of hill) and/or steep slope and/or convex slope were assigned high erosion risk and therefore high implementation priority. The study showed that more than $64 \%$ of the fields were classified into high erosion risk areas. Accordingly, a community-watershed plan was established, revised and approved by the community.
\end{abstract}

Received: 9 July 2013

Accepted: 17 February 2014
Incentive loans to implement SWC measures were distributed to 100 farmers based on the priorities of their fields. Judged by local farmers and using 16 randomly selected fields, $90 \%$ of the targeted areas were correctly identified using the erosion risk map. After two years, the conservation measures had led to marked improvement of soil conservation. The approach is simple and easy to comprehend by the community and provides scientific basis to prioritize the implementation of SWC and to target the most degraded areas, which amplify the impact of these in reducing the vulnerability to land degradation.

Keywords: Flow accumulation; Soil erosion; Community-conservation plan; Olive; Priority map

\section{Introduction}

Soil erosion by water is a persistent environmental problem in the Olive (Olea europaea $c v$. Picual) farms of the Mediterranean areas, where topography is highly rugged, steep lands are cultivated and rainfall is erosive. A recent international assessment has alerted the world to climate change (IPCC 2007), ecosystem and environmental degradation (MEA 2005) and 
natural resources degradation (GEO 2007). Some scientific reports indicated that agricultural practices are partly responsible for the damage of the global environment. Causes of high erosion rates in the mountainous areas are partly due to natural processes, in particular the steepness of the terrain, coupled with heavy rain and partly enhanced by inappropriate land use or agricultural management practices (Cao et al. 2010; Móga et al. 2013).

The high erosion susceptibility of the Mediterranean region is the result of the sporadic and variable amounts of annual rainfall with high rainfall intensities. This is coupled with relatively low organic matter content of the soil and the steep slopes of mountainous areas that make the soil more erodible. Land use further affects erosion processes through continuous tillage practices with no soil cover, overgrazing, and poor land management practices (Poesen \& Hooke 1997). Land degradation in the dryland area is a combination of natural, social and financial inputs.

Changes in precipitation amount and intensity caused by climate change may increase the energy available in rainfall for detaching and carrying sediments. According to Yang et al. (2003), the global average soil erosion is projected to increase approximately $9 \%$ by 2090 due to climate changes.

In addition, soil erosion can result in serious environmental problem, for instance, increased rates of soil erosion are directly associated with nutrient loss, which may reduce agricultural productivity (Bakker et al. 2007) and cause water bodies' eutrophication (Istvánovics 2009). In some cases, advanced stages of soil erosion, such as rill and gully erosions, can devastate entire agricultural lands and became unusable for cultivation (Valentin et al. 2005; Kirkby and Bracken 2009).

Conservation practices are based on designing and building earthen, semi-lunar-shaped waterharvesting bunds around Olive trees. Farmers are trying to reduce erosion by implementing continuous stone wall or fences that are made of plants in horizontal lines across the field. The surface roughness is increased by annual grass cover. Farmers are also practicing tillage using animals or mechanization two or three times a year. Farmers did realize the extent of erosion, but claimed that the investments demanded to conserve the soil were too costly.
Land degradation could be reduced by conservation systems that control soil erosion, enhance olive productivity and increase income for the farmers. A study conducted by Ziadat et.al.(2013) in the same area indicated that no rill erosion was observed on the field where interventions of the continuous stone bunds was implemented, while in the adjacent field without any interventions, an amount of $13.6 \mathrm{t} \mathrm{ha}^{-1}$ of soil loss was recorded, resulted from the 26 observed rills. The study also showed that the amount of sediment captured by SWC interventions (semicircular bounds around olive tree) varied significantly across 8 selected fields and among 10 rainfall events (2010-2012 rainy seasons).

Land-use changes are the main processes shaping land-cover variation, ecosystem dynamics, and shifting landscape patterns. In the Mediterranean region, soil degradation is perceived as a major threat due to land use pattern and projected climate change (Yilmaz et al. 2010). Land use further affects erosion processes in several ways, e.g. by soil displacement by tillage practices, overgrazing, controlled burning and land abandonment (Poesen \& Hooke, 1997). The typical landscape of the northern east of Syria consists of steep hillsides and deeply incised valleys. The valley bottoms are gentler because of the accumulation of slope wash and deposits (De Pauw et al., 2004).

Olive is well adapted to the Mediterranean environment. It is a hardy tree that can grow on poor, shallow soils and will survive periods of low rainfall (Olive Bureau 2001). However, many scientists argue that erosion is the major problem associated with olive cultivation (Tombesi et al. 1996; Beaufoy 2001). As land degradation is increasing, land managers are looking for new methods to manage and monitor erosion, which can assist for a targeted and cost-effective conservation intervention by identifying most vulnerable landscapes and setting of priorities for implementing these interventions.

Erosion/deposition modeling is an important approach that can be used for land management. However; using this approach in complex terrain within a geographical information system (GIS) requires a high resolution digital elevation model (DEM), reliable estimation of topographic parameters, and formulation of erosion models 
adequate for digital representation of spatially distributed parameters. Meanwhile, to estimate soil loss is particularly difficult, because there are so many variables, some occurring naturally, such as soil and rainfall, and others are related to management practices, therefore, empirical or process-based models are necessary to include the effects of all variables.

Most erosion and sediment studies have been carried out to provide a quantitative erosion map (Singh et al. 1992; Martinez-Casanovas 2003; Ygarden 2003; Essa 2004). Boggs et al. (2001) assessed soil erosion risk based on a simplified version of RUSLE using digital elevation model (DEM) data and land-units maps. Raoofi et al. (2004) attempted to recognize and map erosion in the Taleghan basin in Tehran Province by using image processing techniques. Erosion was categorized into rill, gully and no erosion regions by using images from the fusion of ETM+ bands and Cosmos images. Also, a map of ground truth from eroded regions was produced from field observations. Measurements indicated an approximate $80 \%$ accuracy for the categorization. For erosion field studies, Raglione et al. (1999), in southern Italy, reported soil losses for 27 rainfall events during a 2-year period was 0.7 and 82.8 $\mathrm{t} \cdot \mathrm{ha}^{-1}$ for permanent cover and conventional tillage, respectively. Kosmas et al. (1996) reported annual soil losses less than $0.03 \mathrm{t} \mathrm{ha}^{-1} \mathrm{yr}^{-1}$ in Greek olive orchards grown under semi-natural conditions with a cover of natural vegetation.

The vulnerability map and the erosion prone areas can be extracted by applying spatial analysis in GIS, using topographic parameters generated from DEM. Flow accumulation, for example, is used to generate a drainage network, based on the direction of flow of each cell. By selecting cells with the greatest accumulated flow, a network of highflow cells is generated. Slope also calculates the maximum rate of change between each cell and its neighbours, for example, the steepest downhill descent for the cell (the maximum change in elevation over the distance between the cell and its eight neighbours). The lower the slope value, the flatter the terrain is and vice versa. In addition to flow and slope, surface curvature is represented by two important attributes, plan curvature and profile curvature. The profile curvature is in the direction of the maximum slope, and the plan curvature is perpendicular to the direction of the maximum slope. A positive curvature indicates the surface is upwardly convex at that cell. A negative curvature indicates the surface is upwardly concave at that cell. A value of $o$ indicates the surface is flat. Curvature of the landscape can be used to identify zones of enhanced erosion and deposition (ESRI 2004).

There has been a growing interest in the use of participatory approaches in the natural resource management, agriculture and rural livelihoods sectors. These have included: participatory rural appraisal, farmer participatory research, participatory technology development, participatory action research, participatory learning and action, gender and stakeholder analysis, community-based natural resource management, and sustainable livelihoods approach. Rhoades (1998) indicated that the adoption of social participatory action through the involvement of the local farmers, for assessing the resource base conditions has become an attractive methodology for many conservation and development studies. Farmer participatory monitoring and evaluation of soil erosion risk assessments as well as basic education about the processes of erosion can promote farmer's stewardship of natural resources (Wander and Drinkwater 2000; Kessler and Stroosnijder 2006).

In this study, a map of erodible land has been created using topographic parameters for small catchment. Susceptible areas for erosion were targeted with suitable soil and water conservations measures to improve productivity and enhance environmental sustainability.

\section{Materials and Methods}

\subsection{The study area}

The study was conducted in the village of Maghara (latitude $36^{\circ} 32^{\prime} 24^{\prime \prime} \mathrm{N}$ and longitude $36^{\circ} 39^{\prime} 21^{\prime \prime} \mathrm{E}$ ), about $125 \mathrm{~km}$ Northwest of Aleppo, Syrian Arab Republic (Figure 1). The village is located within a watershed with an area of $1.4 \mathrm{~km}^{2}$. The area is typified by steep hillsides with flat divides and deeply incised valleys. The topography tends to level out at the foot slopes because of the accumulation of gravelly slope wash and talus 
deposits. The area has a Mediterranean-type climate; the altitude is about 500-700 m above sea level, and it receives an average annual rainfall of 525 mm, concentrated between September and June. The mean annual temperature is $17^{\circ} \mathrm{C}$. The soil temperature regime is thermic and the moisture is Xeric. The annual potential evaporation is about 1200-1600 $\mathrm{mm}$. (Bruggeman et al. 2005; Barneveld et al. 2009).

Entisols constitute the dominant soil order of the hillslopes, and the main soilscape units are lithic xerorothents and xerorochrept (Louis Berger International 1982). The former are mainly medium- to fine-textured, mostly shallow soils of low and medium organic matter content, and the latter are well to moderately drained, very shallow, light grey to dark greyish-brown, moderately finetextured soils occupying the narrow summits and the upper slopes. In general, the

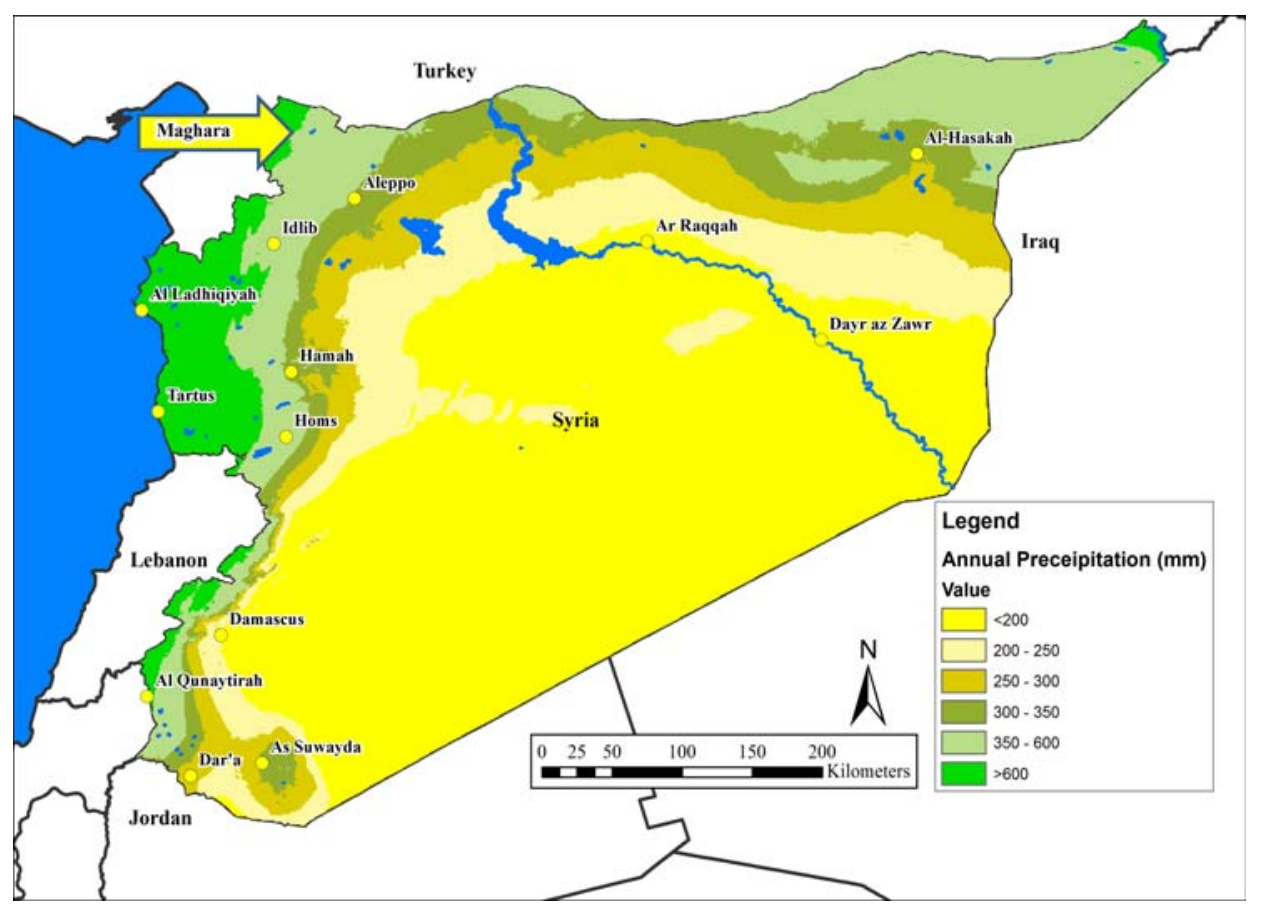

Figure 1 Location of the study area within Syria.

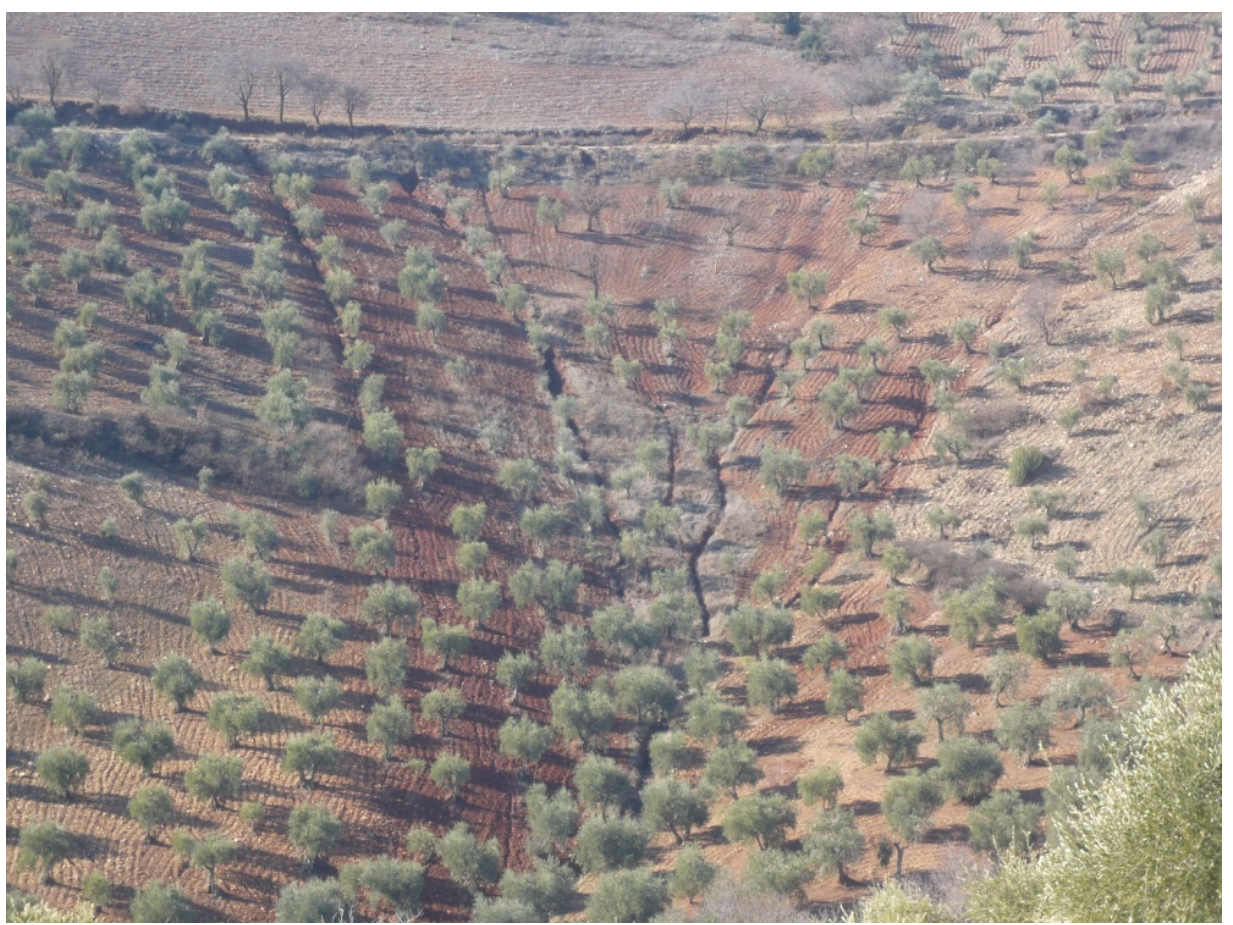

Figure 2 Landscape and topographic condition of the study area (Rill and gully erosion in the olive farm). soils are less than 30

$\mathrm{cm}$ thick; the soils contain a few angular limestone fragments, which occupy approximately $10 \%$ of the solum. The limestone bedrock is found within 10 to $20 \mathrm{~cm}$ of the surface on the upper slopes. The vegetative cover has been subjected to strong anthropogenic changes, including clearing of the native forest from about 1910 (De-Pauw 2001). In the ensuing period, farmers have replaced native forest with olive groves, as well as almond, walnut and different forestry plantations. Rill and gully 
erosion can be observed in the hilly olive farms (Figure 2).

\subsection{Erosion risk (priority) map}

DEM was created by interpolating from contour lines digitized from $20 \mathrm{~m}$ contour spacing topographical maps. GIS layers of flow accumulation, slope degree and surface curvatures were derived within ArcGIS to produce priority erosion map. A smoothing (average) filter was applied to these layers to remove small areas before proceeding with further analysis. Following rainfall events, water flows from areas of convex curvature and accumulates in areas of concave curvature and from upper to lower positions within the landscape. This process is known as flow accumulation and is usually remarkable at the upstream segment of the catchment. Flow accumulation is a measure of the land area that contributes runoff to an area where surface water can accumulate. This parameter was considered as relevant to this study, because it defines the locations of water concentration after rainfall and those locations are likely to have a high erosion incidence. Li et al. (2013) indicated that sediments are mainly generated from cultivated land on steep slopes and deposited on fields located on the flat areas.

Although pixels with low flow accumulation might not have high erosion rates, these are important to enhance erosion in lower fields in the same catena (topo-sequence). Therefore, reducing erosion and runoff from these is considered prerequisite to reduce erosion of lower positions within the hill slope sequence. Farmers indicated that SWC interventions implemented on fields which are located at lower positions within the catena (topo-sequence) are not effective because these fields receive erosive runoff from the upper fields. In addition to flow accumulation, slope steepness and land curvature were considered in producing erosion risk (priority) maps owing to their importance as determinants of soil erosion in these mountainous areas.

Flow accumulation can be explained as the number of pixels, or area, which accumulate runoff to a particular pixel. Flow accumulation have been classified into three categories $(0-2,3-5$ and $>5$ pixels), land curvature into two categories (convex and concave/linear), and slope steepness into three
Table 1 Erosion risk classification based on the flow accumulation (FA), land curvature (SC) and slope steepness values (SSV) to identify priority for SWC implementation.

\begin{tabular}{|r|l|c|c|}
\hline $\begin{array}{r}\text { FA } \\
\text { (Pixels) }\end{array}$ & $\begin{array}{l}\text { SC } \\
\text { (Class) }\end{array}$ & $\begin{array}{c}\text { SSV } \\
\text { (Percent) }\end{array}$ & Risk \\
\hline $0-2$ & Convex & $0-5$ & $\mathrm{H}$ \\
\hline $0-2$ & Convex & $5-10$ & $\mathrm{H}$ \\
\hline $0-2$ & Convex & $>10$ & $\mathrm{H}$ \\
\hline $0-2$ & Concave/Linear & $0-5$ & $\mathrm{H}$ \\
\hline $0-2$ & Concave/Linear & $5-10$ & $\mathrm{H}$ \\
\hline $0-2$ & Concave/Linear & $>10$ & $\mathrm{H}$ \\
\hline $3-5$ & Convex & $0-5$ & $\mathrm{M}$ \\
\hline $3-5$ & Convex & $5-10$ & $\mathrm{H}$ \\
\hline $3-5$ & Convex & $>10$ & $\mathrm{H}$ \\
\hline $3-5$ & Concave/Linear & $0-5$ & $\mathrm{~L}$ \\
\hline $3-5$ & Concave/Linear & $5-10$ & $\mathrm{M}$ \\
\hline $3-5$ & Concave/Linear & $>10$ & $\mathrm{H}$ \\
\hline$>5$ & Convex & $0-5$ & $\mathrm{~L}$ \\
\hline$>5$ & Convex & $5-10$ & $\mathrm{M}$ \\
\hline$>5$ & Convex & $>10$ & $\mathrm{H}$ \\
\hline$>5$ & Concave/Linear & $0-5$ & $\mathrm{~L}$ \\
\hline$>5$ & Concave/Linear & $5-10$ & $\mathrm{~L}$ \\
\hline$>5$ & Concave/Linear & $>10$ & $\mathrm{M}$ \\
\hline
\end{tabular}

The erosion risk (priority for SWC) is classified into three levels: H-high, M-moderate, L-low.

categories (0-5, 5-10 and >10\%) (Table 1). Pixels were then classified into three erosion risk classes (high, moderate and low). The classification was based on ranges of these values and rationalization based on erosion severity. For example, all pixels located at the top of hillslopes (flow accumulation o-2 pixels) were classified as high erosion risk regardless of slope curvature or steepness. This is because these pixels are not only exposed to high erosion but also generate runoff that accumulate and moves to the fields down the hill and produce high erosion. Fields located directly below these fields (with flow accumulation 3-5 pixels) were given higher erosion risk than pixels located further down, depending on slope curvature and steepness. The classification was refined in the field using erosion evidences and the judgement of local farmers to create final priority map. The use of GIS facilitated many iterations to arrive at reasonable results, which was finally appraised by the community.

\subsection{Community participation and field boundaries}

Field survey, using aerial photo map was 
conducted, with participation of local community, to draw the farms' boundary, ownership and current conservation practices. The layouts were then digitized and transferred into electronic layer in ArcGIS. Land ownership map was overlaid with the erosion risk map to show the erosion status of each field. Sixteen fields were randomly selected to verify the erosion risk (priority) map. Community members and farmers who own these fields were asked to present their judgment on the agreement between the erosion risk map and the erosion status in their fields. The effectiveness of implementing SWC interventions to reduce erosion in these fields was also used as a criterion in this evaluation.

\section{Results and Discussion}

\subsection{Flow accumulation, slope and land curvature}

In Figure 3, flow accumulation map was created to calculate accumulated flow as the accumulated weight of all cells flowing into each downslope cell in the output raster. If no weight raster is provided, a weight of one is applied to each cell, and the value of cells in the output raster will be the number of cells that flow into each cell. In Figure 3, the top right layer shows the number of cells that flow into each cell classified into three classes (see Table 1). Slope curvature indicates where the surface is convex,
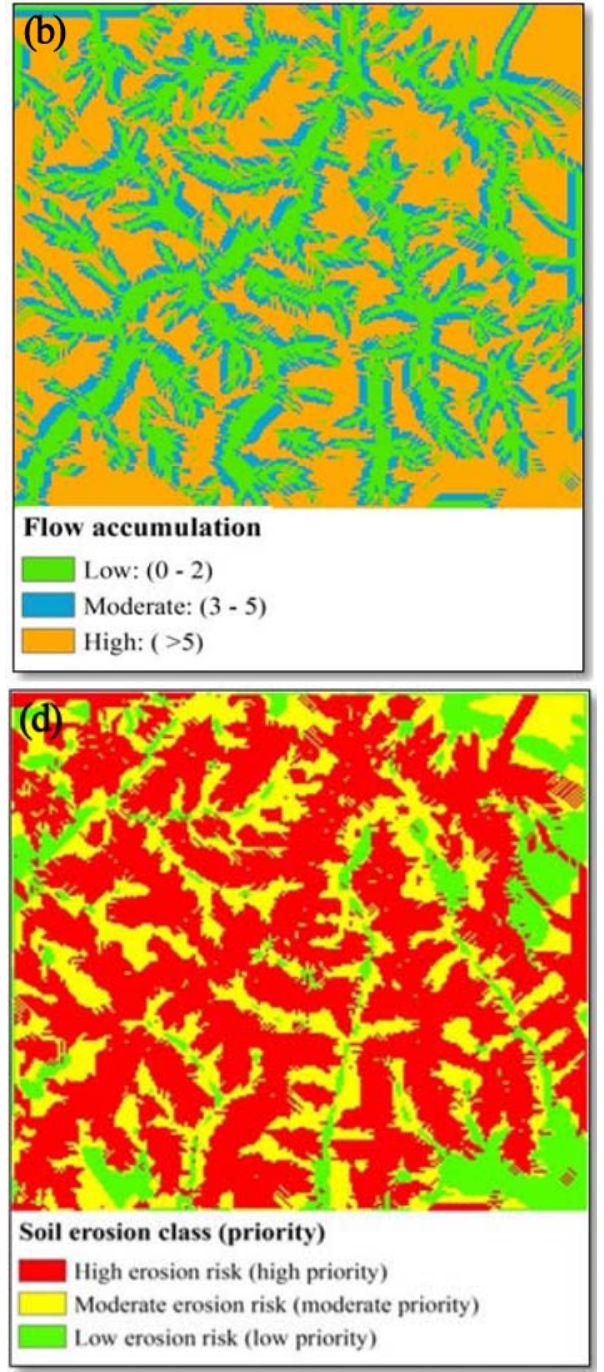

Figure 3 Layer overlay to generate soil erosion map: (a) slope curvature, (b) flow accumulation, (c) slope classes, (d) erosion risk (priority) map.

concave or linear. Convexity (negative values of a grid) is associated with the divergence of flow identifying regions where the propensity for rill and gully erosion is great, while concavity (positive values of a grid) indicates convergence of flow therefore depicting ridges and areas of sediment deposition. Flat areas (zero values on a grid) indicate flat deposition zones.

\subsection{Layers overlay and priority map}

About two-third of the watershed was classified as area with high erosion risk (high priority), while $26 \%$ was classified as medium erosion risk and only $7 \%$ with low erosion risk (Figure 3). There was an obvious relationship 
between the distribution of areas with different erosion classes and topographic parameters of flow accumulation, slope and land curvature. Mehnatkesh et al. (2013) indicated that slope, wetness index, catchment area and sediment transport index, explained about $76 \%$ of the total variability in soil depth at a mountainous area. Close inspection of Figure 3 shows an obvious visual agreement between the three layers of curvature, flow accumulation and slope steepness in one hand and the final erosion-risk (priority) map, on the other hand. Top of hillslopes (summits) were generally classified as high erosion-risk areas although slope is less steep than other positions on the topo-sequence. This is because these areas generate runoff that will adversely affect the rest of the terrain below. Therefore, if no proper conservation measures are implemented, these areas will continue delivering runoff to lower positions and whatever measures are implemented in the affected fields there will be no obvious impact in reducing land degradation. This rational was obtained when discussing with farmers, who claimed that the effectiveness of SWC varies among their fields. In Syria, SWC structures such as semicircular stone bunds, continuous stone walls bench terraces, and vegetation strips on contour lines were implemented by the local farmers (Figure 4).

Upon inspection, it was obvious that SWC effectiveness was much less on fields which are located in lower positions and/or field that receive significant flow from upper fields. As indigenous knowledge, the farmers assess the SWC effectiveness by the amount of erodible soil from the upper fields to the lower fields. Olive fields are divided by their ownership among several farmers. Farmers in the upstream are responsible to protect downstream's fields from eroded soil during heavy rain storms. Therefore, by implementing SWC structures, the downstream famers assured that these techniques have significantly reduced soil erosion and their effectiveness was positive. A recent study by Ziadat et al. (2013) indicated that fields that are located below steep fields with large area and without barrier at the borders capture more sediment, indicating higher erosion rates. Also, the occurrence of rain events with high intensity seems to be a significant factor in determining the amount of sediment captured by the conservation structures. Discussion with the farmers highlighted the need for rules and/or criteria to facilitate the prioritization of SWC implementation to guarantee obvious effectiveness. The idea of collective action through the organization of implementation according to the erosion risk of farmers' fields as well as the negative effect of their fields on other fields was accepted and the priority map was generated, with their participation, and was considered as criteria to arrange the SWC implementation. Soil erosion hazard maps can be an essential tool in erosion prone areas as they explain and display the distribution of hazards and areas likely to be affected to different magnitudes (Rejaur et al. 2009).

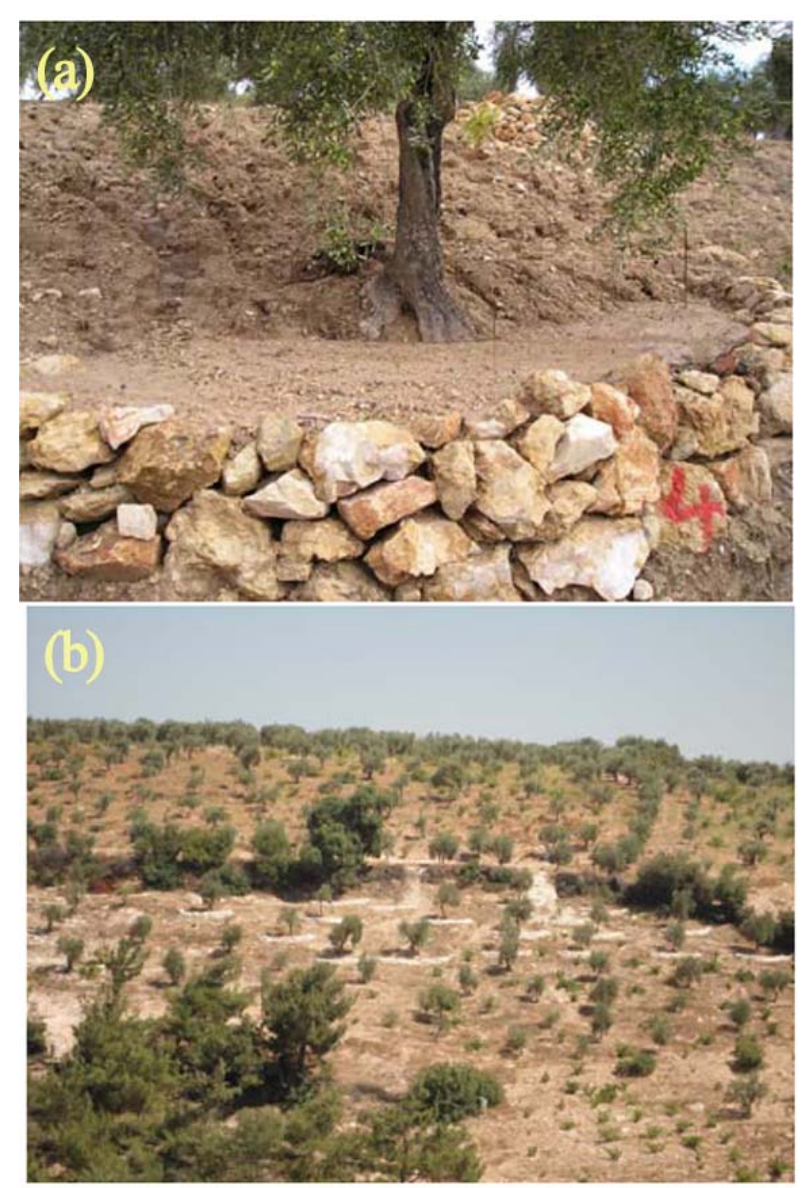

Figure 4 Soil and water conservation practices: (a) semi-circular bunds, and (b) stone walls in Olive field within the study area.

\subsection{Farmers' verification of the priority map}

The priority map was overlaid with boundaries of the farmers' fields (Figure 5). These boundaries 
were mapped in the field using satellite image as background and with the participation of the community, and the owner(s) of each parcel was identified. A group of farmers visited some fields (verification fields - Figure 5) and we compared the erosion risk (priority) indicated by the map with field conditions. The Bureau of Land Management (BLM), USA and other land management agencies have used various techniques to monitor surface erosion. The relative degree of erosion can be estimated by observing certain visual signs, such as pedestals, rills, litter movement, flow patterns, deposition, and gully features. Visual indicators provide a qualitative assessment of erosion. Major advantages of using visual indicators include: It allows for a relatively quick process; Many observations can be made during a field trip; The potential erosion problems that require site-specific monitoring can be identified (Ypsilantis WG 2011). Therefore, by involving local farmers in the field erosion assessment, a ground truth verification process (gathering data from the field about soil erosion type and severity and compare it with the maps) using randomly selected 16 fields indicated that $90 \%$ of the targeted areas were correctly identified using the erosion risk map. Most of the fields classified as high erosion risk were located at higher positions with steep slope and convex shape. Scientists and farmers judged these to be an obvious source of erosive runoff for those fields located below these fields, and arrived at a comparable judgment for the fields classified with moderate or low erosion risk. Li et al. (2013) reported that the cultivated land on steep slopes that are located in the upper part of landscape are a major sources of sediment delivered to the flat areas located in the lowland within the same landscape.

The farmers said that the erosion risk map classified their fields into a relevant classification and with guidance from scientists and they are willing to use it as a base for prioritizing the implementation of SWC interventions. They found this rational to be much better than the existing approach, where loans for implementing SWC interventions are distributed without taking into consideration the priority of the fields. They also thought that such classification, if accepted by the whole community, will avoid bias among the beneficiaries and help to stop erosion from fields which contribute to lower fields. A community meeting was arranged to explain the map and the whole approach. In this meeting farmers who participated in the verification of the priority map stand side by side with scientists to explain the approach and the benefits of adopting such rational in distributing the loans in order to reduce erosion and improve productivity. The community endorsed this and confirmed that the classification of their fields into different erosion risk classes should be used to prioritize the implementation of SWC intervention at the village (watershed) level.

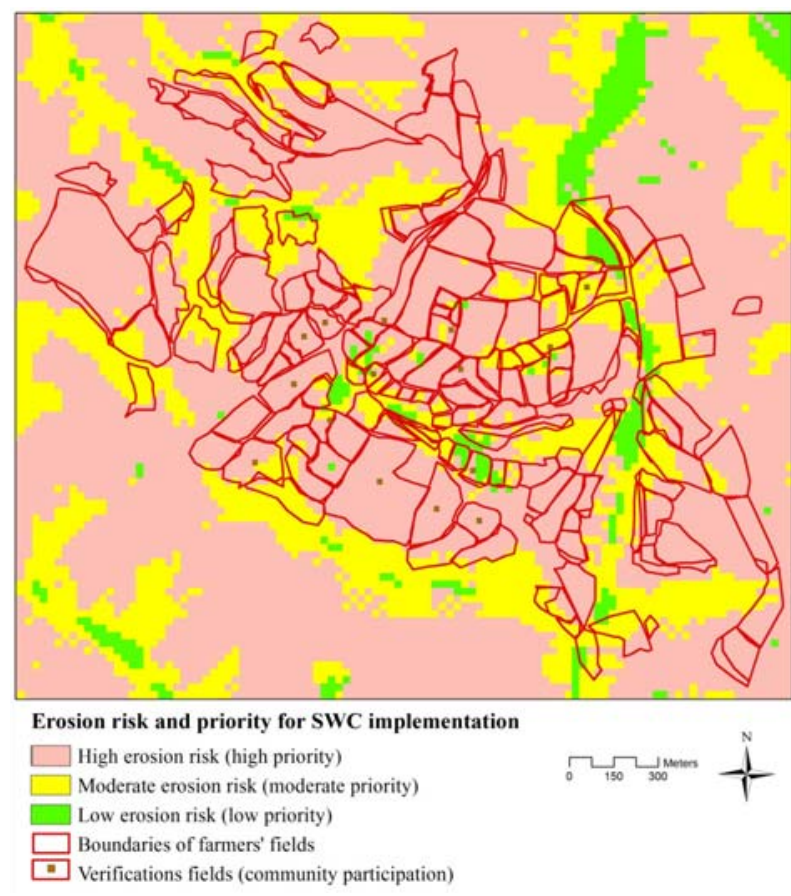

Figure 5 Erosion risk (priority) classes overlaid with boundaries of farmers' fields and the location of ground verification fields.

To support the implementation of SWC interventions, the community secured a fund from the Small Grant Program (SGP) of the GEF - UNDP in Syria. They elected a committee called the Land Management and Diversification Committee. The farmers and their families apply for the Committee and clarify the measures and activities to be performed. The committee examines the applications and determines their priority in obtaining the loan according to the importance of measures or activities to reduce erosion and improve the income, the economic situation of the farmer and his family and their ability to repay the loan. The farmer and his family should repay the 
loan within two years. The committee shall examine new applications and the granting of loans for other farmers and their families in the village and this means that all the inhabitants of the village will benefit from these small interest-free loans, according to priorities, and also farmers can benefit more than once.

The community used to follow an approach to screen the applications by the farmers and to decide priorities for funding. However, the approach does not follow clear criteria and therefore the community members complain about two major weaknesses. First, farmers and their families felt some bias in distributing the loan and therefore some has lost their interest in benefiting, although their farms are under high risk of land degradation and loss of productivity. Second, farmers were complaining that although they apply SWC interventions on their farms, erosion features are still obvious in their fields. By inspecting some fields, and through the discussion with the owners, it was concluded that erosion is still high in some cases because erosion is not only generated within the field but is influenced by erosive runoff being received from upper fields in the same catena (topo-sequence). The derived priority maps were presented to the community and the rational of these priorities were discussed and approved by the community. The community endorsed the use of this map as a base to determine the priority of each field and to distribute loans based on this priority. Accordingly, a community-watershed plan was established, revised and approved by the community. Incentive loans to implement SWC measures were distributed to 100 farmers based on the priorities of their fields. After two years, the conservation measures had led to marked improvement in soil conservation (Ziadat et al. 2013). In this study, two agricultural fields were selected to compare rill formation in fields with and without SWC structures, the study concluded that the semi-circular bunds reduced total rill erosion from 138.9 to 82.9 t/ha (60\% reduction). Also, eight agricultural fields where soil and water conservation (SWC) structures were implemented were selected to assess soil erosion. Each field was characterized in terms of area, slope (steepness and Curvature), soil, land use and characteristics of upslope field. The study indicated that the community-watershed plan approach is simple and easy to comprehend by the community and provides scientifically based rules to facilitate prioritization of SWC implementation in response to climate change.

\section{Conclusion}

The applied methodology, based on GIS analysis of topographic data, made it possible to locate the areas where soil loss is high and to prioritize areas to implement soil and water conservation interventions. The community participation was important to verify the relevance and accuracy of the soil erosion risk (priority) maps and to motivate the community to use the map as a base for distributing loans to implement the conservation interventions. The approach is easy and uses available information and could be applied in mountainous areas with similar challenges. The approach was tested in a small area with homogeneous soils, land use and climate pattern, hence, topography is the main driver for the variations in soil erosion. Implementing this approach in a larger area with heterogeneous soils, land use and climate pattern will need fine-tuning before users can adopt the approach. The study shows that the integration of GIS and socioeconomic aspects has a potential to provide a basis to target susceptible areas for soil erosion with appropriate soil and water conservation. This helps in implementing efficient and sustainable conservation plans with high acceptance by the community.

\section{Acknowledgement}

The authors would like to acknowledge the contribution of Kasem Al-Ahmad, Adriana Bruggeman, Mira Haddad, the General Commission for Scientific Agricultural Research (GCSAR), the Extension offices and Agricultural Directorates in Afrin, the community of Maghara (Afrin - Syria) and would like to thank the CocaCola foundation and the CGIAR $\mathrm{CRP}_{5}$ program on Water, Land and Ecosystems for supporting this study. 


\section{References}

Bakker MM, Govers G, Jones RA, et al. (2007). The effect of soil erosion on Europe's crop yields. Ecosystems 10: 1209-1219. DOI: $10.1007 /$ s10021-007-9090-3

Barneveld RJ, Bruggeman A, Sterk G,et al. (2009). Comparison of two methods for quantification of tillage erosion rates in olive orchards of North-West Syria. Soil \& Tillage Research 103(1): 105-112. DOI: 10.1016/j.still.2008.09.006.

Beaufoy G (2001) The environmental impact of olive oil production in the European Union: practical options for improving the environmental impact. European Commission, Brussels, Belgium. pp 1-73.

Boggs G, Devonport C, Evans K, et al. (2001) GIS-based rapid assessment of erosion risk in a small catchment in the wet/dry tropics of Australia. Land Degradation \& Development 12: 417-434. DOI: 10.1002/ldr.457.

Bruggeman A, McCann I, Pala M, et al. (2005). Improved decision making for deficit irrigation of wheat in northern Syria. Written for presentation at the 2005 ASAE Annual International Meeting Sponsored by ASAE, Tampa Convention Center, Tampa, Florida, USA, 17-20 July 2005.

Cao S, Lee Kt, Ho J, et al. (2010) Analysis of runoff in ungauged mountain watersheds in Sichuan, China using Kinematicwave-based GIUH Model. Journal of Mountain Science 7: 157-166. DOI: 10.1007/s11629-010-0256-7.

De-Pauw E (2001) Review of work at the Yakhour experimental site, stabilization of marginal steeplands in northern Syria. Report to INIA. Aleppo, Syrian Arab Republic, ICARDA.

De Pauw E, Oberle A, Zoebisch M (2004) Overview of land cover and land use in Syria: base year 1989/1990. Asian Institute of Technology, Klong Luang, Thailand.

ESRI, Environmental Systems Research Institute (2004) ArcGIS 9: Using ArcGIS geostatistical analyst. ESRI, Redlands, California, USA.

Essa S (2004) GIS modeling of land degradation in Northern Jordan using Landsat imagery. Available online: http://www.isprs.org/istanbul2004/comm4/papers/401.pdf (Accessed on 1 October 2012)

GEO Data Portal (2007) UNEP's online core database with national, sub-regional, regional and global statistics and maps, covering environmental and socio-economic data and indicators. United Nations Environment Programme, Geneva, Switzerland. Available online: http://www.unep.org/geo/data or http://geodata.grid.unep.ch (Accessed on 13 February 2013)

IPCC (2007) Climate change 2007. The Physical Science Basis, Summary for Policymakers. Contribution of Working Group 1 to the Fourth Assessment Report of the Intergovernmental Panel on Climate Change, Geneva, Switzerland.

Istvánovics V (2009) Eutrophication of lakes and reservoirs. In: Likens GE (Ed.), Encyclopedia of Inland Waters. Academic Press, London, UK. pp 157-165. DOI: 10.1016/B978012370626-3.00141-1

Kessler CA, Stroosnijder L (2006) Land degradation assessment by farmers in Bolivian mountain valleys. Land Degradation \& Development 17: 235-248. DOI: 10.1002/ldr.699

Kirkby MJ, Bracken LJ (2009). Gully processes and gully dynamics. Earth Surface Processes and Landforms 34: 18411851. DOI: $10.1002 /$ esp.1866.

Kosmas CS, Moustakas N, Danalatos NG, et al. (1996) The Spata Field Site: I. The impacts of land use and management on soil properties and erosion. II. The effects of reduced moisture on soil properties and wheat production. In: Brandt J, Thornes J (Eds.),Mediterranean Desertification and Land use. John Wiley \& Sons, Ltd., Chichester, USA. pp 207-228.

Li J, Wen A, Long Y, et al. (2013) Using 137Cs tracing methods to estimate soil redistribution rates and to construct a sediment budget for a small agricultural catchment in the three gorges reservoir region, China. Journal of Mountain Science 10: 428-436. DOI: 10.1007/978-94-009-7290-2_5.

Louis Berger International (1982) Land Classification/soil Survey Project of the Syrian Arab Republic. Volume 2 (Reconnaissance soil survey of Syria, 1: 500,000). Louis Berger International, inc, South Dakota State University.
Remote Sensing Institute, USA. Agency for International Development, Syria.

Martinez-Casasnovas JA (2003) A spatial information technology approach for the mapping and quantification of gully erosion. Catena 50: 293-308. DOI: 10.1016/So3418162(02)00134-0.

MEA, Millennium Ecosystem Assessment (2005) Living beyond Our Means. Natural Assets and Human Well-being. Island press, Washington, DC, USA.

Mehnatkesh A, Ayoubi S, Jalalian A, et al. (2013) Relationships between soil depth and terrain attributes in a semi arid hilly region in western Iran. Journal of Mountain Science 10: 163172. DOI: $10.1007 / \mathrm{s} 11629-013-2427-9$.

Móga J, Kiss K, Szabó M, et al. (2013) Hazards and landscape changes (degradations) on Hungarian karst mountains due to natural and human effects. Journal of Mountain Science 10: 16-28. DOI: $10.1007 /$ s11629-013-2400-7

Olive Bureau. 2001. Olive Bureau Statistics. Ministry of Agriculture and Agrarian Reforms, Syrian Arab Republic.

Poesen JWA, Hooke JM (1997). Erosion, flooding and channel management in Mediterranean environments of southern Europe. Progress in Physical Geography - Research Gate 21: 157-199. DOI: 10.1177/030913339702100201

Raglione M, Toscano P, Angelini R, et al. (1999) Olive yield and soil loss in hilly environment of Calabria (Southern Italy). Influence of permanent cover crop and ploughing. International Meeting on Soils with Mediterranean Type of Climate, 4-9 July 1999, Barcelona, Spain.

Raoofi M, Refahi H, Jalali N, et al. (2004) A study of the efficiency of digital processing methods of satellite images to map and locate soil erosion. Iranian Journal of Agricultural Sciences 35 (4): 797-807.

Rejaur Rahman M, Shi ZH, Chongfa C (2009) Soil erosion hazard evaluation - An integrated use of remote sensing, GIS and statistical approaches with biophysical parameters towards management strategies. Ecological Modelling 220: 1724-1734. DOI: 10.1016/j.ecolmodel.2009.04.004

Rhoades R (1998) Participatory Watershed Research and Management: Where the Shadow Falls. Gatekeeper Series, No. SA81. International Institute for Environment and Development, London, UK.

Singh G, Babu R, Narain P, et al. (1992) Soil erosion rates in India. Journal of Soil and Water Conservation 47: 97-99.

Tombesi A, Michelakis N, Pastor M (1996) Recommendations of the working group on olive farming production techniques and productivity. Olivae 63: 38-51.

Tubeileh A, Turkelboom F, Bruggeman A, et al. (2007). Olives: the fruits of partnership. ICARDA Caravan, 24: 32-34.

Valentin C, Poesen J, Li Y (2005) Gully erosion: impacts, factors and control. Catena 63: 132-153. DOI: 10.1016/j.catena. 2005.06.001.

Wander MM, Drinkwater LE (2000) Fostering soil stewardship through soil quality assessment. Applied Soil Ecology 15: 6173. DOI: 10.1016/So929-1393(00)ooo72-X

Yang D, Kanae S, Oki T, et al. (2003) Global potential soil erosion with reference to land use and climate changes. Hydrological Processes 17: 2913-2928. DOI: 10.1002/hyp.1441

Ygarden L (2003) Rill and gully development during an extreme winter runoff event in Norway. Catena 50: 217-242. DOI: 10.1016/So341-8162(02)00138-8

Yilmaz OY, Sevgi O, Tecimen HB, et al. (2012) Land use pattern at Alacam mountainous range land (submediterraneanTurkey) due to edaphic and physiographical factors. Journal of Environmental Biology 33(Suppl. 2): 355-61.

Ypsilantis WG (2011) Upland soil erosion monitoring and assessment: An overview. Tech Note 438. Bureau of Land Management, National Operations Center, Denver, USA

Ziadat F, Oweis T, Al-Wadaey A, et al. (2013) Soil conservation and water harvesting packages to improve community livelihoods and fight land degradation in the mountains of Syria. Technical Report, International Center for Agricultural Research in the Dry Areas (ICARDA), Amman, Jordan. 
吴二校: 1、springer版权信息被遮住, 已调整； 2 . 其他已改。

Lisa三较: 有些颜色和表格问题已经修改, 有部分图题第一个单词的首字母没有大写,已改. QIU-Adjust the layout of the figures and tables. 